\title{
Kajian pengembangan kendaraan listrik di Indonesia: prospek dan hambatannya
}

\author{
Victor Tulus Pangapoi Sidabutar \\ Pusat Pendidikan dan Pelatihan Perdagangan, Kementerian Perdagangan, Indonesia \\ E-mail korespodensi:victor.sidabutar@yahoo.com
}

\begin{abstract}
The transportation sector is now starting to shift from using fossil fuels to electricity that is more environmentally friendly because this sector contributes the most greenhouse gas emissions. The development of the use of electric vehicles is growing rapidly with the largest market is China followed by Europe and the United States. The development of electric vehicles is very dependent on the policies issued by the country. Indonesia desires to be one of the centers of the world's electric vehicle industry and for that, it must pay attention to challenges in terms of cost, standards, power generation, incentive assistance, communication security, and a framework for integration. In addition to this, if Indonesia wants to attract investors, it must pay attention to infrastructure readiness, ease of doing business, government policies, and research and development.
\end{abstract}

Keywords:Electric vehicles, Chllenges, Policies, Infrastructure, Ease of doing research and development business

\begin{abstract}
Abstrak
Sektor transportasi saat ini mulai beralih dari menggunakan bahan bakar fosil ke energi listrik yang lebih ramah lingkungan karena sektor ini terbanyak menyumbang emisi gas rumah kaca. Perkembangan penggunaan kendaraan listrik berkembang dengan cepat dengan pasar terbesar adalah Tiongkok diikuti wilayah Eropa dan Amerika Serikat. Perkembangan kendaraan listrik sangat bergantung dari kebijakan yang dikeluarkan oleh negaranya. Indonesia berkeinginan menjadi salah satu pusat industri kendaraan listrik dunia dan untuk itu harus memperhatikan tantangan dalam hal biaya, standar, pembangkit listrik, bantuan insentif, keamanan komunikasi dan kerangka kerja dalam pengintegrasian. Selain hal tersebut, jika Indonesia ingin menarik investor maka harus memperhatikan kesiapan infrastruktur, kemudahan untuk berbisnis, kebijakan pemerintah serta riset dan pengembangan.
\end{abstract}

Kata kunci:Kendaraan listrik,Tantangan,Kebijakan,Infrastruktur, Kemudahan berbisnis riset dan pengembangan

\section{PENDAHULUAN}

Penggunaan berkelanjutan bahan bakar fosil telah menyebabkan peningkatan yang stabil dari konsentrasi $\mathrm{CO}_{2}$ di atmosfer menjadi 400,26 ppm pada tahun 2015 (Abas et al., 2015). Sektor transportasi adalah kontributor utama bagi konsumsi bahan bakar fosil dunia dan emisi gas rumah kaca. Pada tahun 2013, energi yang dihabiskan di 
sektor transportasi terdiri $27,6 \%$ dari total konsumsi energi di dunia dan 92,6\% dari jumlah ini didasarkan pada konsumsi produk minyak. Selain itu, emisi CO2 yang dihasilkan oleh sektor transportasi adalah 22,9\% dari total emisi CO2 di dunia (Woo et al., 2017). Untuk memperlambat perubahan iklim dan mengembangkan sumber daya energi yang berkelanjutan, masyarakat dunia harus mendukung transisi energi besar dari bahan bakar fosil ke energi terbarukan dan penggunaan sumber energi alternatif. Semakin berkurangnya bahan bakar fosil di masa depan memotivasi para peneliti, perancang, produsen mobil, dan agen-agen transportasi untuk mencari sumber daya alternatif, seperti tenaga listrik, untuk kendaraan (Mehar et al., 2015).

Gelombang pertama kebangkitan dalam penjualan EV dimulai pada awal 1970-an, dipicu terjadinya krisis minyak pertama di California. Pada 1980-an, baterai EV mengalami kebangkitan karena pada saat itu timbul kekhawatiran tentang pasokan bahan bakar fosil dan polusi udara terkait transportasi (Ajanovic, 2015). Pada periode ini, sejumlah produksi baterai EV yang ada ditujukan untuk kebutuhan eksperimental. Terjadi kebangkitan pada awal 1990-an dikarenakan kekhawatiran yang berkembang terkait masalah iklim. EV adalah alternatif transportasi yang dapat mengurangi emisi gas rumah kaca (GRK) dan meningkatkan keamanan energi (Kang et al., 2016). Manfaat lingkungan dan sosial dari EV hanya dapat diwujudkan melalui adopsi oleh publik sebesar-besarnya.

Di Indonesia, Presiden Joko Widodo berencana ingin menjadikan Indonesia sebagai salah satu pusat industri mobil listrik dunia (Kompas, 2019). Salah satu upaya untuk mempercepat hal tersebut, pemerintah berupaya melakukan hilirisasi industri nikel yang nantinya diproduksi menjadi baterai lithium yang merupakan komponen utama dalam mobil listrik. Selain itu, aturan ekspor nikel dalam Peraturan Menteri Perdagangan Nomor 1 Tahun 2017 tentang Ketentuan Ekspor Produk Pertambangan Hasil Pengolahan dan Pemurnian diperketat dimana nikel dengan kadar rendah, yakni dibawah 1,7\% tidak diperkenankan lagi untuk diekspor mulai Desember 2019. Pertanyaan yang kemudian muncul, apakah akan semudah itu terbentuknya industri mobil listrik di Indonesia?

\section{METODE}

Metodologi penelitian yang digunakan didasari teori analisis Porter's Five Forces adalah model yang digunakan untuk mengidentifikasi dan menganalisis lima kekuatan kompetitif yang membentuk suatu industri dan membantu menentukan kelemahan dan kekuatan industri. Analisis Five Forces sering digunakan untuk mengidentifikasi struktur industri untuk menentukan strategi perusahaan. Model Porter dapat diterapkan pada setiap segmen ekonomi untuk memahami tingkat persaingan dalam industri dan meningkatkan profitabilitas jangka panjang suatu perusahaan (Bruijl, 2018). Analisis dilakukan pada 5 hal yaitu: 1) Hambatan bagi pendatang baru, 2) Daya tawar pembeli, 3) Daya tawar pemasok, 4) Hambatan bagi produk pengganti, dan 5) Tingkat persaingan Bisnis

\section{Hambatan bagi pendatang baru}

Hambatan terkait dengan pendatang baru seperti: 1).Belum adanya kebijakan penggunaan dan pengembangan kendaraan listrik di Indonesia, 2).Tingginya harga dan biaya kepemilikan kendaraan listrik bagi masyarakat Indonesia, 3).Perbedaan tingkat kemudahan berusaha di Indonesia untuk memulai pabrikan di Indonesia, 
4).Memerlukan modal yang besar (contoh: mengadakan sendiri infrastruktur pengisian daya di tempat umum)

\section{Daya tawar pembeli}

Daya tawar pembeli terkait dengan: 1).Belum ketatnya regulasi dalam pengurangan gas rumah kaca, 2)Tingginya harga dan biaya kepemilikan kendaraan listrik dibandingkan kendaraan konvensial, 3).Belum tersedianya infrastruktur pengisian daya di tempat umum

\section{Daya tawar pemasok}

Untuk analisis daya tawar pemasok terkait dengan: 1). Banyaknya pemasok kendaraan listrik di dunia yang dapat diajak bekerjasama, 2).Indonesia merupakan pemain baru dalam industri kendaraan listrik, 3).Terdapat keinginan Indonesia untuk memproduksi sendiri didalam negeri dengan mengandalkan bahan baku lokal

\section{Hambatan bagi produk pengganti}

Selanjutnya terkait dengan hambatan bagi produk pengganti adalah: 1). Harga dan biaya kepemilikan kendaraan konvensional lebih rendah dibandingkan kendaraan listrik, 2).Belum ketatnya regulasi dan insentif dalam penggunaan kendaraan listrik

\section{Tingkat persaingan bisnis}

Selanjutnya untuk tingkat persaingan bisnis dilihat dari: 1).Indonesia masih baru dalam industri kendaraan listrik, 2).Kompetisi dengan merek besar untuk pasar lokal dan ekspor, 3).Tinggi harga beli dan biaya kepemilikan kendaraan listrik dibandingkan kendaraan konvensional, 4).Belum adanya regulasi dan insentif dalam produksi dan pengembangan kendaraan listrik

Kelima hal diatas diukur tingkat tinggi dan rendahnya kekuatan yang ada untuk melihat posisi Indonesia yang bercita-cita ingin menjadi negara penghasil kendaraan listrik di dunia. Dari kelima hal tersebut, diperoleh asumsi sebagai berikut (Gambar 1).

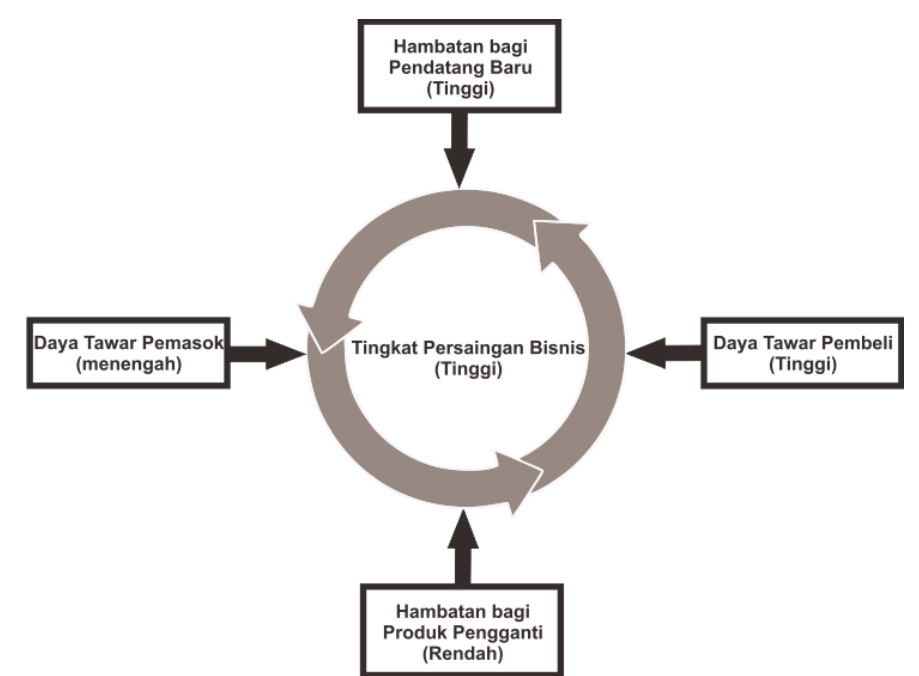

Gambar 1. Analisis tingkat persaingan bisnis kendaraan listrik di Indonesia

\section{Analisa situasi perkembangan penggunaan EV di dunia}

Berdasarkan data dari International Energy Agency (IEA) yang tertuang dalam Global EV Outlook 2019, perkembangan penggunaan EV di dunia saat ini berkembang 
dengan cepat. Pada tahun 2018, armada mobil listrik secara global melebihi 5,1 juta, naik 2 juta dari tahun sebelumnya dan terjadi hampir dua kali lipat jumlah penjualan mobil listrik baru. Republik Rakyat Tiongkok tetap menjadi pasar mobil listrik terbesar di dunia, diikuti oleh Eropa dan Amerika Serikat. Norwegia tetap menjadi pemimpin global dalam hal pangsa pasar mobil listrik sebesar $46 \%$ dari penjualan mobil listrik barunya pada tahun 2018, lebih dari dua kali lipat pangsa pasar terbesar kedua di Islandia sebesar $17 \%$ dan enam kali lebih tinggi dari Swedia tertinggi ketiga di Swedia. $8 \%$ (Gambar 2).

Perkembangan EV sangat didukung oleh kebijakan yang dikeluarkan pemerintah di negara tersebut. Tinjauan baru-baru ini tentang pasar EV utama di AS, Uni Eropa, dan Asia Timur menunjukkan bahwa investasi pemerintah melalui kebijakan publik dapat mengarah pada pertumbuhan pasar EV (Kang et al., 2016). Negara-negara Nordik (Denmark, Finlandia, Norwegia dan Swedia) dalam hal kebijakan menuju ke arah yang sama dengan mengadopsi teknologi smart grid di seluruh wilayah (Valta et al., 2018). Negara-negara terkemuka dalam mobilitas listrik menggunakan berbagai langkahlangkah seperti standar ekonomi bahan bakar ditambah dengan insentif untuk kendaraan nol dan rendah emisi, instrumen ekonomi yang membantu menjembatani kesenjangan biaya antara EV dan konvensional dan dukungan untuk penyebaran infrastruktur pengisian daya (Brady and O'Mahony, 2016; Ruiz et al., 2018; Hauser and Kuhn, 2015; Shareef et al., 2016; Knezovic et al., 2017; Habib et al., 2015; Shaukat et al., 2018; Ahmad et al., 2018).

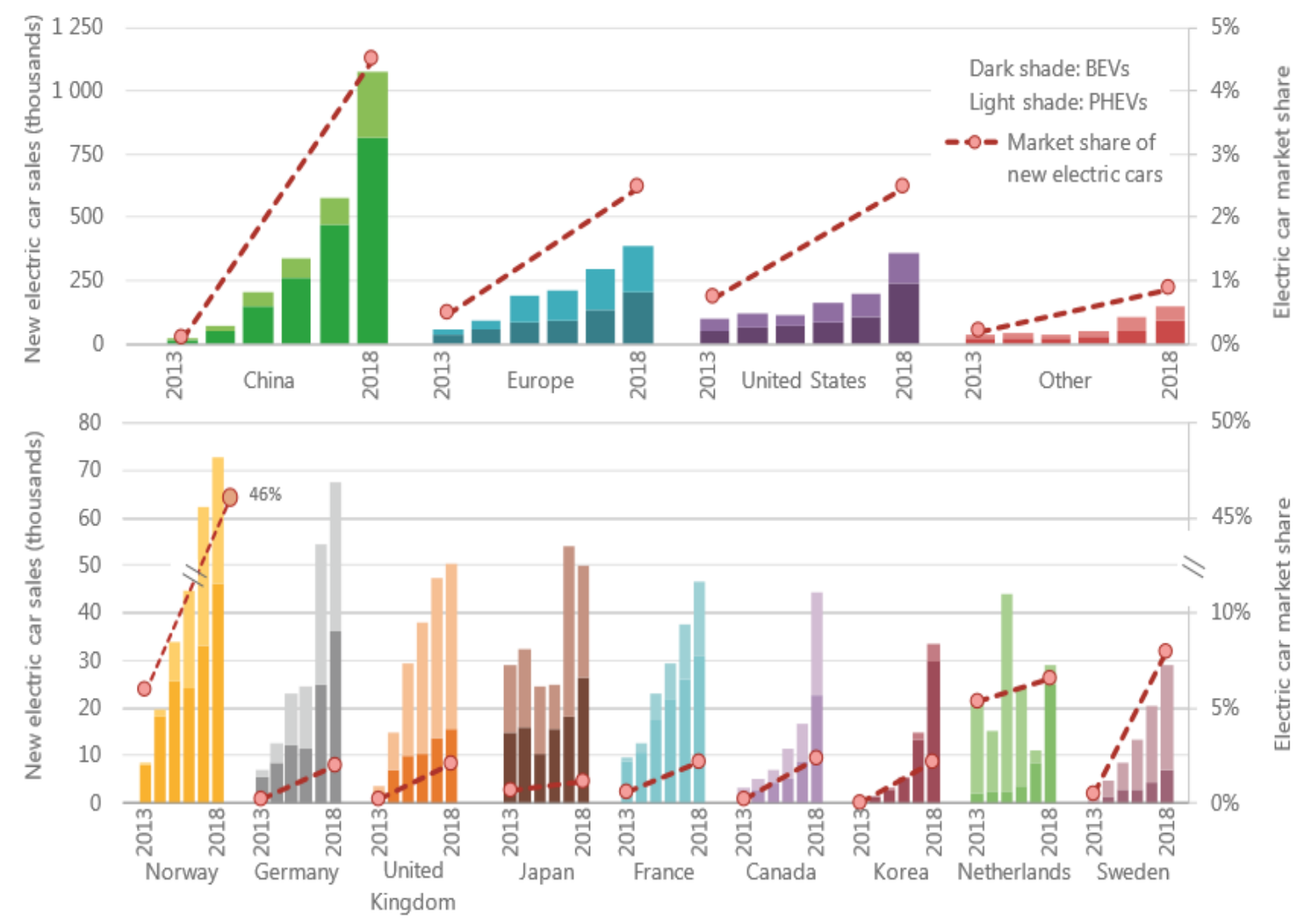

Gambar 2. Penjualan dan pangsa pasar mobil listrik global, 2013-18

Sumber: Till Bunsen et al., 2019 
Catatan: BEVs = Battery Electric Vehicles atau Baterai kendaraan listrik; PHEVs = plug-in hybrid electric vehicles atau kendaraan listrik hibrida colok-masuk. Eropa meliputi Austria, Belgia, Bulgaria, Kroasia, Siprus, Republik Ceko, Denmark, Estonia, Finlandia, Prancis, Jerman, Yunani, Hongaria, Islandia, Irlandia, Italia, Latvia, Liechtenstein, Lithuania, Luksemburg, Malta, Belanda, Norwegia, Polandia, Portugal, Rumania, Slovakia, Slovenia, Spanyol, Swedia, Swiss, Turki dan Inggris. Lainnya termasuk Australia, Brasil, Chili, India, Jepang, Korea, Malaysia, Meksiko, Selandia Baru, Afrika Selatan dan Thailand.

\section{Analisa perkembangan penggunaan kendaraan bermotor di Indonesia dan ASEAN}

Berdasarkan data dari badan pusat statistik (2019) menunjukkan bahwa perkembangan penggunaan kendaraan bermotor di Indonesia selama periode Tahun 2007-2017 terus mengalami peningkatan. Jumlah kendaraan tertinggi yaitu pada jenis kendaraan bermotor, dan diikuti oleh jenis mobil penumpang, mobil barang dan mobil bis. Tingginya penggunaan kendaraan bermotor menyebabkan kota sering terjadi macet dan polusi.

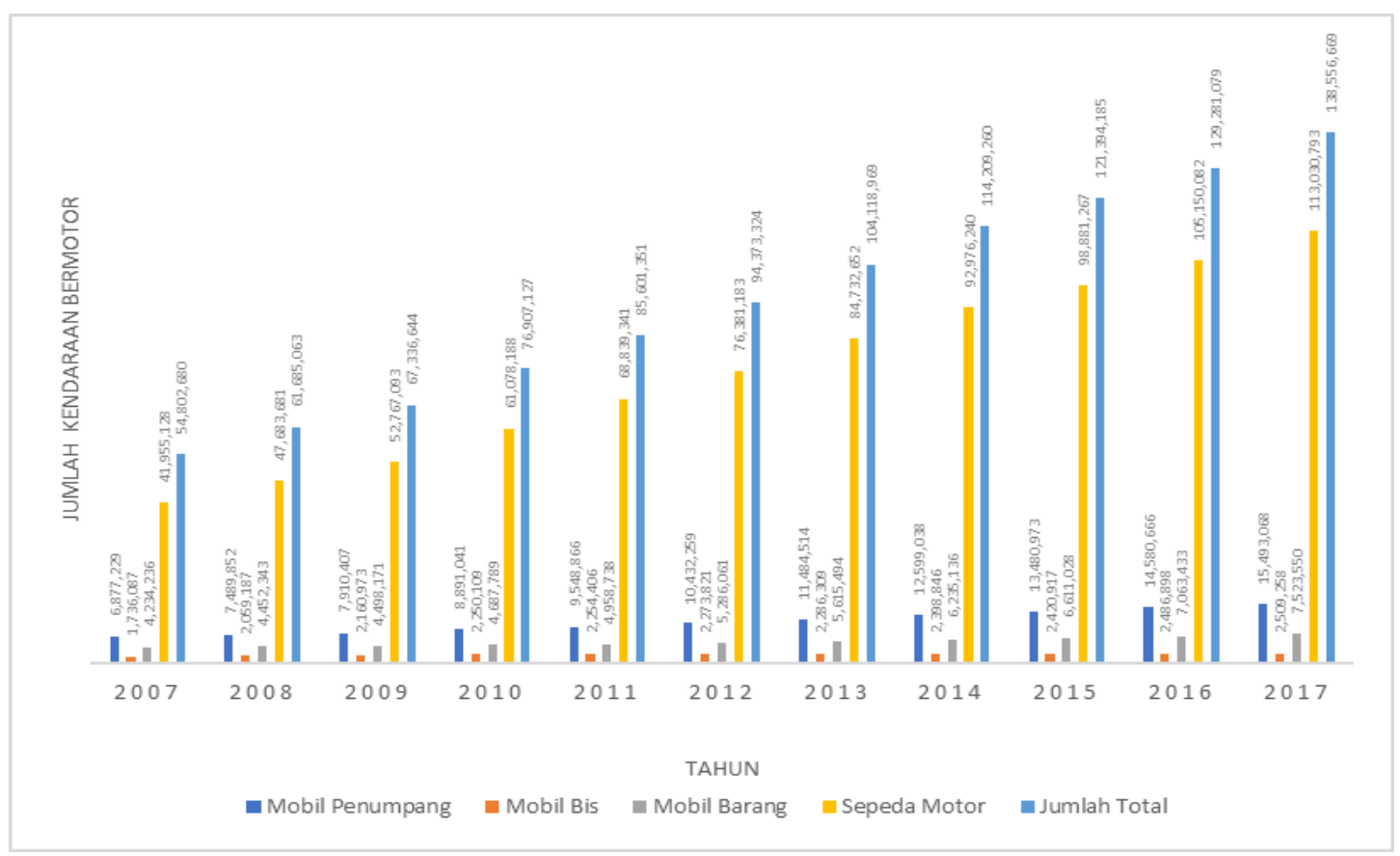

Gambar 3. Perkembangan jumlah kendaraan bermotor menurut jenis, 2007 - 2017 Sumber: BPS, 2019(diolah)

Selanjutnya, jika dilihat perbandingan jumlah unit beberapa negara bagian seperti ASEAN, Indonesia, Brunei, Malaysia, Filipina, Singapura, Thailand, dan vietnam. Jumlah barang (unit) kendaraan cenderung berfluktuasi setiap tahunya. Penjualan tertinggi terjadi pada tahun 2012 dan 2013 hal ini dikarenakan terjadinya boom komodities sehingga pendapatan masyarakat meningkat yang kemudian permintaan juga mengalami peningkatan. 


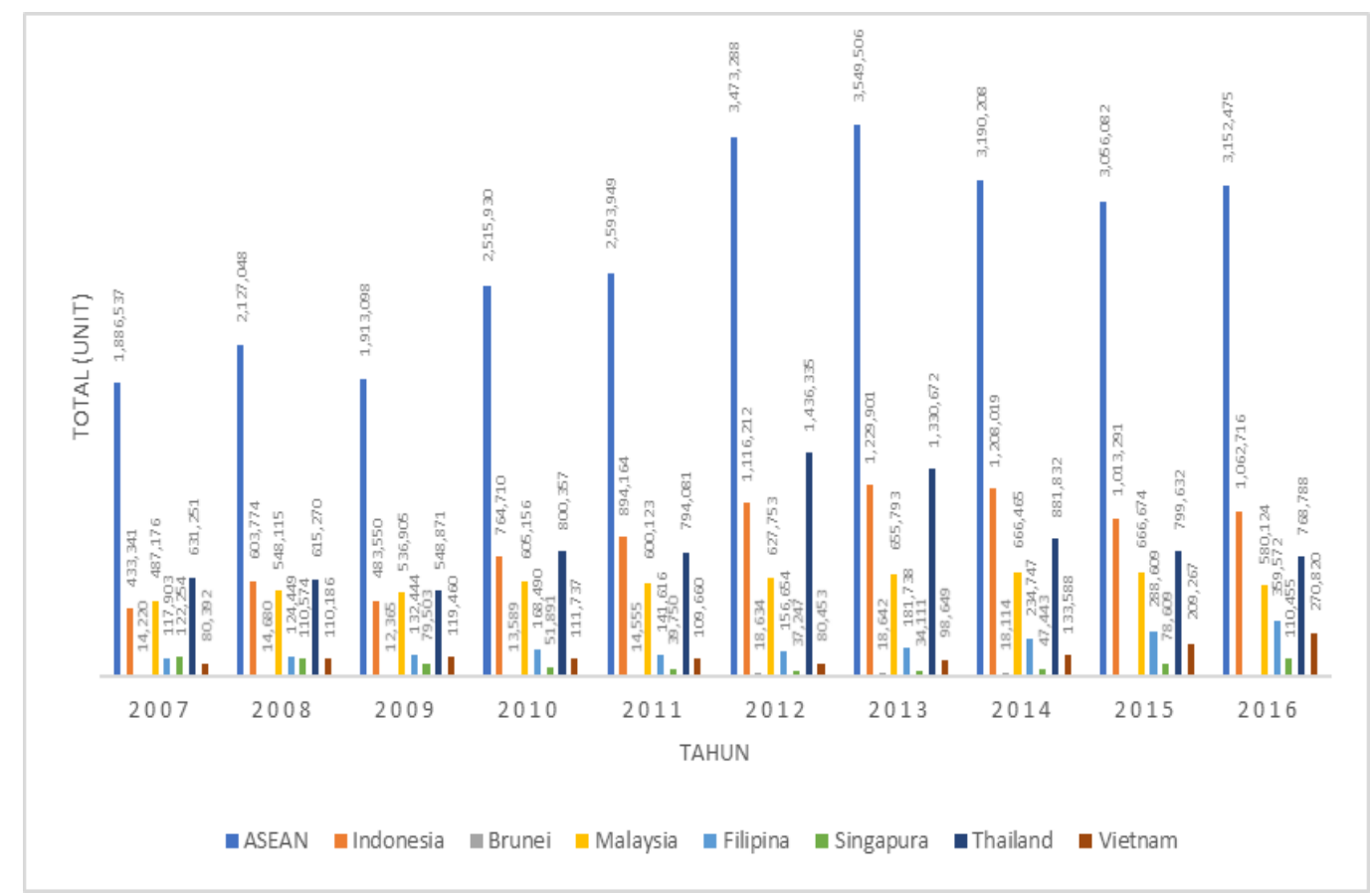

Gambar 4. Pasar otomotif di ASEAN, 2007 - 2016

Sumber: Gaikindo, 2019(diolah)

Berdasarkan data dari BPS (2019) mengenai perkembangan jumlah kendaraan bermotor berdasarkan jenisnya (Gambar 3), telah terjadi peningkatan jumlah kendaraan bermotor secara keseluruhan sekitar 152,8\% dalam kurun waktu 2007 hingga 2017 dimana peningkatan terbanyak terjadi pada jenis sepeda motor $(169,4 \%)$ diikuti mobil penumpang $(125,3 \%)$, mobil barang $(77,7 \%)$ dan mobil bis $(44,5 \%)$. Untuk wilayah ASEAN, peningkatan jumlah permintaan otomotif juga terjadi diangka $67,1 \%$ dalam kurun waktu 2007 - 2016 (Gaikindo, 2019) dengan pangsa pasar terbesar adalah Indonesia dan Thailand (Gambar 4).

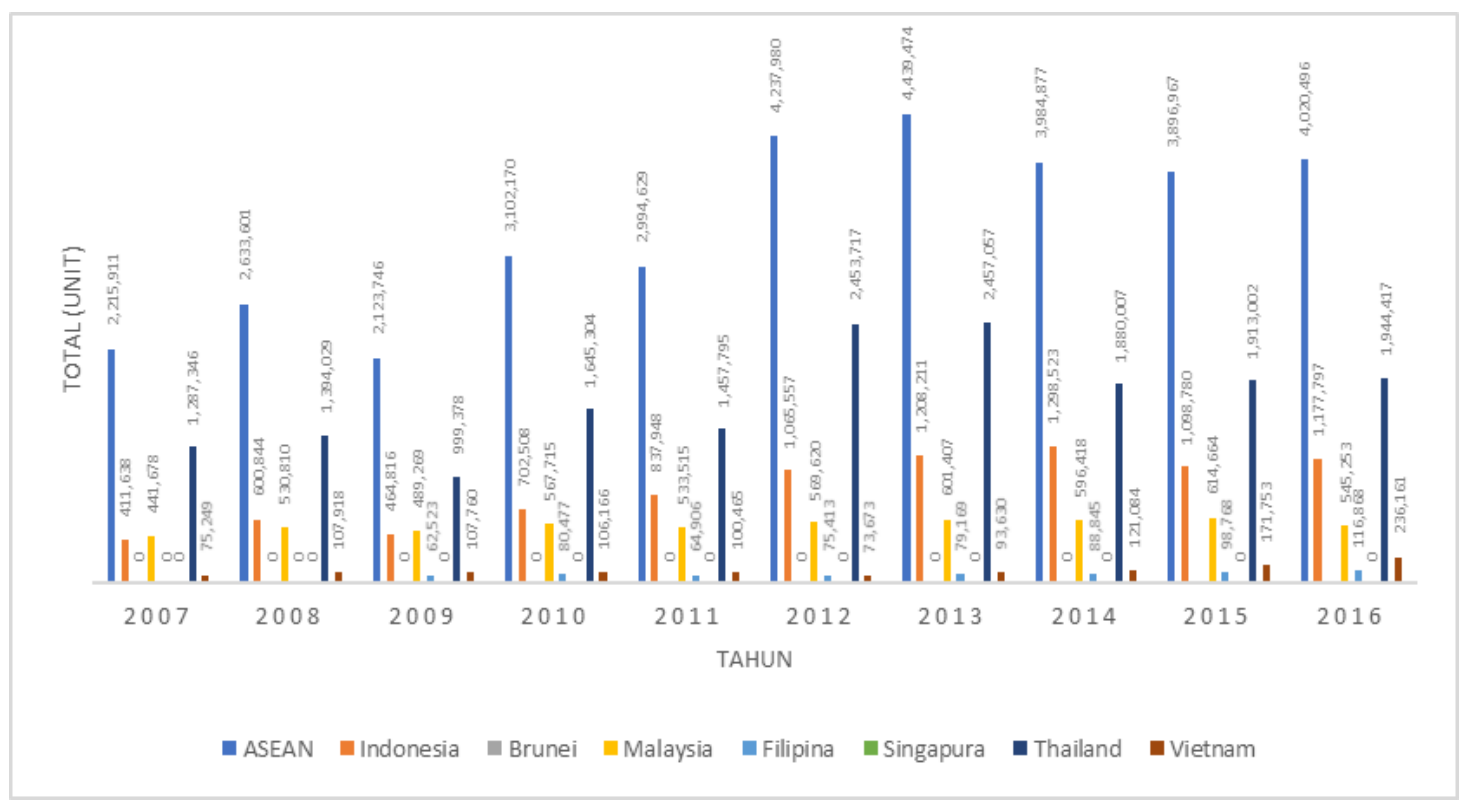

Gambar 5. Produsen otomotif di ASEAN, 2007 - 2016

Sumber: Gaikindo, 2019(diolah) 
Sedangkan untuk produksi kendaraan bermotor di ASEAN, Thailand merupakan produsen utama disusul Indonesia (Gambar 5). Berdasarkan data diatas terlihat pertumbuhan pasar Indonesia dan ASEAN dalam dapat menjadi peluang bagi industri otomotif Indonesia untuk meningkatkan produksinya untuk memenuhi kebutuhan dalam negeri dan juga pasar ASEAN.

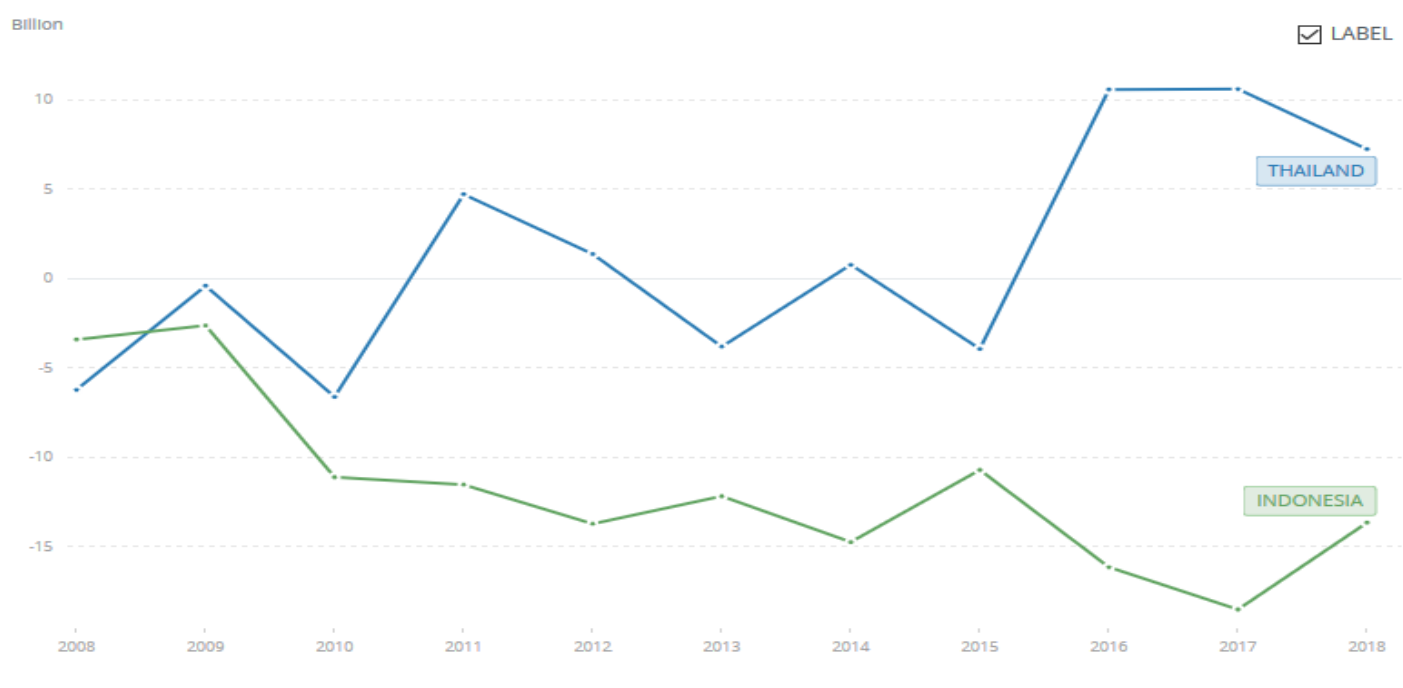

Gambar 6. Investasi Asing Langsung berdasarkan Balance of Payment (Balance of Payment (BoP) dalam USD) kurun waktu 2008 - 2018

Sumber: Worldbank, 2019(diolah)

Ancaman bagi Indonesia di wilayah ASEAN adalah Thailand dimana negara tersebut merupakan produsen utama dan sekaligus merupakan negara yang lebih menarik bagi investor dibandingkan Indonesia (Gambar 6). Salah satu yang membuat Thailand menarik bagi industri otomotif adalah negara tersebut mengadopsi kebijakan perlindungan yang hanya sedikit negara berkembang yang berhasil melakukannya. Selain itu, Thailand mengadopsi kebijakan substitusi impor untuk industri otomotif pada awal 1960-an. Sejak itu, Thailand telah menarik sejumlah besar produsen otomotif, terutama dari Jepang (Kuroiwa, 2017).

Lebih menariknya pesaing Indonesia untuk diajak berinvestasi adalah ancaman bagi Indonesia yang bercita-cita ingin menjadi pusat industri mobil listrik di dunia. Indonesia adalah pasar terbesar di wilayah ASEAN tetapi merupakan pemasok kedua sesudah Thailand di wilayah Asean. Dalam hal teknologi kendaraan listrik, Indonesia masih terbilang baru dan berdasarkan publikasi Bank Dunia pada September 2019, Indonesia tidak bisa mengekspor mobil listrik sebab Indonesia bukan bagian dari rantai pasokan otomotif global (CNN Indonesia, 2019).

\section{Tantangan dalam pengembangan industri kendaraan listrik}

Sejauh ini, pergeseran dari paradigma transportasi jalan berbasis MPD ke elektromobilitas meningkat secara perlahan. Sementara berkendara dengan EV dinilai masih mahal dan tidak nyaman karena rentang tempuh kendaraan yang terbatas dan interval pengisian baterai yang lama, insentif politik untuk menginternalisasi biaya lingkungan dan fase penghentian penggunaan mesin MPD masih cukup lemah (Altenburg, 2014). Standar emisi kendaraan juga belum terlalu menuntut agar dipatuhi. 
Negara Uni Eropa (UE) dan Jepang saat ini sedang menetapkan standar yang paling ambisius (target UE untuk menurunkan rata-rata armada menjadi $95 \mathrm{~g} \mathrm{CO}_{2} / \mathrm{km}$ pada tahun 2020), tetapi bahkan tindakan ini masih jauh dari tingkat jalur dekarbonisasi yang diperlukan untuk mencapai target pemanasan global sebesar $2^{\circ} \mathrm{C}$, yaitu, $10 \mathrm{~g} \mathrm{CO}_{2} / \mathrm{km}$ pada tahun 2050.

Sementara dalam industri pembuatan EV, petahana dan perusahaan wirausaha di industri kendaraan bermotor memiliki model pendekatan inovasi bisnis yang berbeda. Perbedaan yang paling nyata terlihat bahwa pemain lama lebih dibatasi secara kognitif oleh kebergantungan pada jalur yang untuk tetap dekat dengan logika bisnis yang ada daripada perusahaan pendatang baru yang berusaha menciptakan kebutuhan meskipun hasil yang akan diperoleh belum terlalu jelas (Bohnsack et al., 2014). Petahana akan fokus pada efisiensi sebagai sumber utama penciptaan nilai dan perusahaan ini akan mempertimbangkan produksi massal EV dari permulaan dan selanjutnya melakukan penyesuaian terutama pada bagian yang dapat menyebabkan pengurangan biaya, misalnya menurunkan harga pengadaan dengan mengubah pendapatan/model biaya. Namun, mereka membuat beberapa penyesuaian pada beberapa komponen model bisnis. Misalnya, mereka menawarkan layanan tambahan, seperti menyewakan baterai secara terpisah, memberikan garansi yang lebih lama atau opsi untuk menyewa mobil konvensional untuk jarak yang lebih jauh, dan mengalihdayakan pasokan komponen inti yang terkait dengan baterai EV. Namun demikian, sebagian besar praktik ini tidak sepenuhnya baru bagi petahana atau industri mobil, seperti yang biasanya telah diterapkan sebelumnya pada kendaraan MPA lainnya.

Beberapa masalah dan tantangan yang terkait dengan penyebaran dan manajemen EV (Mehar et al., 2015) diantaranya: (1) biaya; (2) standar; (3) pembangkit listrik dan Smart Grid; (4) bantuan insentif; (5) keamanan komunikasi; dan (6) kerangka kerja dalam pengintegrasian. Semua hal tersebut penting dalam upaya agar penyebaran dan penggunaan EV dapat menarik pengguna kendaraan konvensional untuk beralih ke EV.

\section{Biaya}

Bahan baku yang dibutuhkan untuk memproduksi baterai listrik langka dan mahal hingga saat ini. Selain itu masih banyaknya permasalah pada baterai EV dimana keadaan baterai yang dapat menurun dengan cepat dikarenakan kebiasaan pengisian yang buruk atau tidak konsisten saat pengisian misalkan dalam kasus pengisian cepat dan berulang (Mehar et al., 2015). Hal ini dapat menyebabkan banyaknya biaya perawatan tambahan yang diperlukan untuk menjaga operasional EV. Selain itu, solusi rekayasa inovatif baru diperlukan untuk meningkatkan efisiensi EV, untuk meningkatkan kemampuan baterai dan mengatur durasi pengisian daya untuk meningkatkan jarak mengemudi agar lebih maksimum. Intensitas penggunaan baterai EV juga dipengaruhi oleh tiga faktor, yaitu: (1) faktor demografis termasuk variabel individu (misalnya jenis kelamin, usia, pendidikan, pendapatan, dan pekerjaan) dan variabel keluarga (misalnya kepemilikan kendaraan, aksesibilitas kendaraan pada stopkontak dirumah, populasi, dan jumlah Surat Izin Mengemudi); (2) faktor situasional seperti fitur teknis, biaya, atribut lingkungan, dan kebijakan pemerintah; dan (3) faktor psikologis seperti pengalaman, sikap, emosi, kontrol perilaku yang dirasakan, pengaruh masyarakat, dan nilai simbolik (Li et al., 2017). Selain baterai, sistem jaringan listrik pintar (smart grid) untuk stasiun pengisian baterai dan system manajemen armada juga 
memerlukan lebih banyak dana untuk memelihara dan mengelola infrastruktur yang digunakan untuk EV. Pengisian yang terkoordinasi adalah strategi yang paling tepat dan bernilai bagi pemilik dan operator jaringan EV (Habib et al., 2015).

\section{Standar}

Tantangan lain adalah kurangnya standar universal dan peraturan untuk fasilitas listrik dan pasar EV. Setiap negara maju memiliki standar yang berbeda-beda terkait EV yang diproduksi diantaranya standar utilitas energi listrik terhadap variasi pola kemudi/siklus mengemudi (Brady and O’Mahony, 2016), standar baterai (Ruiz et al., 2018), standar desain untuk baterai manajemen sistem (Hauser and Kuhn, 2015), standar pengisian listrik yang terintegrasi dengan aturan kendaraan listrik (Shareef et al., 2016; Knezovic et al., 2017; Habib et al., 2015; (Shaukat et al., 2018), suku cadang (Ruiz et al., 2018; Habib et al., 2015), dan serta platform standar infrastruktur listrik dalam rangka melindungi konsumen (Ahmad et al., 2018; Habib et al., 2015). Pengembangan standar di masa yang akan datang akan membutuhkan kolaborasi yang lebih erat antara organisasi standardisasi (SAE, IEC, dan ECE), peneliti, dan produsen.

\section{Pembangkit listrik dan smart grid}

Mengingat bahwa EV mengkonsumsi sejumlah besar energi listrik, smart grid menghadapi tantangan besar karena harus memastikan pembangkitan dan pengelolaan energi yang diperlukan. Hal ini dikarenakan tidak seperti mobil konvensional yang berbasis bahan bakar, mobil listrik terutama dirancang untuk berkendara pada waktu yang tidak lama dan jarak relatif pendek dibandingkan kendaraan konvensial (Brady and O'Mahony, 2016). Untuk itu diperlukan jaringan pengisian dibanyak tempat pengisian kendaraan dari pembangkit listrik (Vehicle to Grid, V2G). Teknologi V2G saat ini masih sangat baru (Tan et al., 2016), dimana dapat menimbulkan masalah berikutnya, yaitu: (1) degradasi baterai, (2) biaya investasi yang tinggi, dan (3) hambatan sosial. Infrastruktur pengisian juga merupakan komponen penting dalam pengembangan EV (Shaukat et al., 2018) dimana tantangan terbesar jika dibandingkan memproduksi baterai dengan biaya terjangkau adalah mengembangkan infrastruktur pengisian daya EV untuk skala nasional.

\section{Bantuan insentif}

Tingginya biaya EV, stasiun pengisian, dan infrastruktur terkait tetap menjadi tantangan karena penetrasi pasar mobil listrik masih belum terlalu tinggi. Untuk mendanai proyek transportasi di masa depan, diperlukan kerja sama antara industri mobil listrik, perusahaan listrik, dan pemerintah. Beberapa inisiatif yang sebelumnya diusulkan telah berupaya untuk mempromosikan pembuatan, pemasaran, dan penjualan EV. Pemerintah di delapan negara Eropa (Perancis, Jerman, Hongaria, Italia, Belanda, Norwegia, Polandia, dan Inggris) telah mengusulkan insentif yang bertujuan untuk meningkatkan penjualan EV. Insentif yang diberikan diharapkan dapat memainkan peran penting dalam terobosan pasar EV, tetapi penetrasi pasar yang lebih besar hanya dapat dicapai jika harga EV yang ditawakan lebih kompetitif (Lévay et al., 2017). Di Tiongkok, pemerintah memberikan subsidi kepada industri EV berupa insentif untuk produk kendaraan listrik yang dihasilkan seperti: (1) BEV; (2) PHEV; (3) Sel bahan bakar mobil; (4) Bus listrik; (5) Plug-in bus hybrid; (6) sel bahan bakar kendaraan komersial; (7) Kapasitor Super / Bus Lithium titanate. Di samping insentif pemerintah 
pusat, banyak kota besar di Cina mendorong produksi dan pemasaran kendaraan listrik murni dan hybrid di distrik mereka. Biasanya, insentif pajak diberikan kepada pembuat mobil lokal, yang berbasis di kota itu sendiri atau provinsi (Masiero et al., 2016).

\section{Keamanan komunikasi}

Konektivitas tingkat tinggi ini membuatnya sangat menantang untuk mengamankan kendaraan pintar. Entitas jahat dapat membahayakan kendaraan yang tidak hanya membahayakan keamanan kendaraan tetapi juga keselamatan penumpang. Serangan keamanan apa pun dapat memengaruhi pengoperasian smart grid, stasiun pengisian daya dan mobil listrik. Misalnya, pemalsuan dan perubahan voltase atau informasi level saat ini dapat membakar komponen elektronik di EV dan stasiun pengisian daya (Mehar et al., 2015). Smart grid dan sistem manajemen kendaraan akan melakukan proses pertukaran informasi secara real time dalam jumlah yang tidak sedikit, seperti pengisian informasi terkait stasiun pengisian daya, status baterai EV, informasi lalu lintas, dan kejadian tak terduga pada smart grid (Mehar et al., 2015). Kendaraan terhubung ke infrastruktur tersebut melalui internet sehingga mempersatukan kendaraan kedalam sistem Internet of Things (IoT) dimana entitas berbahaya dapat membahayakan kendaraan yang tidak hanya membahayakan keamanan kendaraan tetapi juga keselamatan penumpang (Dorri et al., 2019). Persyaratan keamanan dunia maya harus menjadi yang utama terkait dengan kesadaran akan ancaman itu. Oleh karena itu, serangan harus dideteksi dan perlawanan harus segera dilakukan terhadap serangan itu. Namun, karena Smart grid tersebar dalam area yang besar dengan jutaan titik sambungan, titik redistribusi, atau titik akhir komunikasi (node) yang hampir merupakan jaringan komunikasi terbuka yang membuatnya sulit untuk mengamankan setiap node terhadap serangan (Kabalci, 2016). Selain itu, transmisi informasi yang tidak dienkripsi tentang informasi pribadi dan lokasi pelanggan yang mengancam privasi pelanggan dan perusahaan penyedia jasa V2G dimana bocornya informasi pelanggan, lokasi data, data meteran, konfigurasi data hingga jumlah tarif dan pembayaran (Han and Xiao, 2016).

\section{Kerangka kerja dalam pengintegrasian}

Salah satu hambatan utama bagi konsumen beralih dari kendaraan konvensional ke EV adalah masih tingginya total biaya kepemilikan dari HEV, PHEV dan BEV tanpa adanya subsidi dibandingkan biaya kepemilikan kendaraan konvensional (Palmer et al., 2018). Selain itu, terbatasnya jangkauan kendaraan listrik masih menjadi penghalang kunci terhadap penyerapan massa EV. Hal ini dapat diatasi dengan cara berikut, diantaranya: (1) peningkatan jarak tempuh kendaraan; (2) memperbanyak infrastruktur pengisian publik yang akan memberi pengemudi kepercayaan diri bahwa mereka dapat menyelesaikan perjalanan mereka dan meningkatkan daya kendaraan mereka saat dibutuhkan (Heidrich et al., 2017). Agar transportasi hijau menjadi kenyataan, kita tidak dapat fokus pada satu aspek transportasi tertentu dan mengabaikan faktor-faktor lain yang dapat mempengaruhi manajemen energi. Kerangka kerja yang terintegrasi penuh di mana semua entitas sadar energi diperlukan untuk memungkinkan transportasi berkelanjutan yaitu Sistem manajemen transportasi pintar yang lengkap yang saling terintegrasi (Mehar et al., 2015). Integrasi Sistem Manajemen Transportasi tidak mungkin dilakukan tanpa kerja sama dan kolaborasi produsen mobil, ilmuwan, perusahaan listrik, pemerintah, dan organisasi standar. 


\section{Analisa kesiapan indonesia dalam pengembangan kendaraan listrikDukungan Kesiapan infrastruktur}

Ketika merancang strategi pengendali pada yang bertujuan untuk menyediakan layanan pengisian daya untuk baterai kendaraan listrik di tempat umum maupun di rumah, banyak aspek yang harus dipertimbangkan yaitu pemodelan baterai, pengisian dan standar komunikasi pada perangkat lunak dan juga persyaratan pengisian daya pengguna agar sesuai dengan profil mengemudi mereka (Hu et al., 2016).

Sebagai sumber daya, listrik di Indonesia saat ini bersumber dari Pembangkit Listrik Tenaga Uap (61,60\%), Pembangkit Listrik Tenaga Gas dan Uap (16,13\%), Pembangkit Listrik Tenaga Air (7,65\%), Pembangkit Listrik Tenaga Diesel $(7,16 \%)$ dan Pembangkit Listrik Tenaga Lainnya $(7,46 \%)$ dengan total listrik yang dibangkitkan sebesar 262.661,38 Gwh dan listrik yang didistribusikan sebesar 222.963,73 Gwh dengan pulau Jawa yang menerima distribusi terbanyak sebesar dengan 159,837 Gwh $(71,69 \%)$ (BPS, 2018). Hal ini akan menjadi tantangan terbesar bagi pemerintah jika jadi mengembangkan kendaraan listrik yang digunakan secara nasional dikarenakan akan terjadi permintaan pasokan listrik dari seluruh daerah di Indonesia dan tantang terberat adalah penambahan daya listrik untuk daerah luar pulau Jawa.

\section{Dukungan kemudahan berbisnis}

Kemudahan berbisnis Indonesia pada tahun 2019 berada pada peringkat 73 (Worldbank, 2019) yang meningkat dibandingkan sebelumnya diharapkan dapat menarik masuknya investor luar ke dalam negeri. Momentum terbaik adalah saat terjadi perang dagang antara Amerika Serikat (AS) dengan Tiongkok pada tahun 2018 dengan produk yang terkena dampak sebagian besar berasal dari AS dan Tiongkok. Indonesia dapat memanfaatkan pengaruh tarif tinggi yang diterapkan pada barang impor yang masuk kepada negara tersebut. Pengaruh dari tarif yang diterapkan Tiongkok paling serius pengaruhnya adalah untuk produk pesawat, kendaraan lainnya, tekstil dan pakaian jadi. Di sisi lain, di Tiongkok pengaruh dari tarif AS yang menjadi masalah serius adalah untuk produk mesin, peralatan listrik, bahan kimia dan logam (Onyusheva et al., 2019). Tetapi Indonesia gagal memanfaatkan momentum tersebut dan Thailand adalah negara yang paling cepat memanfaatkan momen tersebut dengan mengumumkan insentif untuk menarik perusahaan yang terkena imbas dari perang dagang AS dengan Tiongkok (CNBC, 2019). Meskipun peringkat kemudahan berbisnis Indonesia meningkat, tetapi data tersebut hanyalah mewakili Jakarta dan Surabaya (Worldbank, 2019). Berdasarkan data dari Asia Competitiveness Institute (ACI) tahun 2016, terlihat bahwa nilai daya saing dari tiap provinsi bervariasi dari yang tertinggi adalah DKI Jakarta $(3,2008)$ dan terendah Papua $(-1,5192)$. Hal ini menunjukkan bahwa investasi yang masuk ke Indonesia tidak akan merata dan hanya tersebar di wilayah yang mendukung masuknya investasi (Tabel 1). Sebagai perbandingan, DKI Jakarta memiliki kinerja jauh di atas rata-rata pada keempat faktor yang mendukung daya saing yaitu (1) Stabilitas Ekonomi Makro; (2) Pengaturan Pemerintah dan Kelembagaan; (3) Kondisi Keuangan, Bisnis dan Tenaga Kerja; dan (4) kualitas hidup dan pembangunan infrastruktur dibandingkan calon Ibu Kota baru di Kalimantan Timur (Gambar 7). Demikian pula dalam sub faktor dari pengaturan pemerintah dan kelembagaan yang menunjukkan bahwa Kalimantan Timur memiliki angka di bawah rata-rata yaitu (1) Institusi, Pemerintahan dan Kepemimpinan dan (2) Kompetisi, Standar Peraturan dan Supremasi Hukum (Gambar 8). 


\section{Dukungan kebijakan pemerintah}

Pemerintah Indonesia dapat menggunakan insentif dalam kebijakan yang dikeluarkan untuk menarik masuknya investasi masuk ke Indonesia dan juga untuk menarik penduduknya untuk menggunakan kendaraan listrik. Insentif kebijakan merupakan cara yang efektif untuk memperoleh peningkatan penjualan EV dengan meningkatkan daya tarik untuk beralih dari kendaraan konvensional ke kendaraan listrik (Langbroek et al., 2016).

Tabel 1. Peringkat daya saing keseluruhan aci 2016 Provinsi Indonesia

\begin{tabular}{|c|c|c|c|}
\hline \multicolumn{2}{|c|}{ Daya saing keseluruhan di Tahun 2016} & \multirow{2}{*}{ Provinsi } & \multirow{2}{*}{ Wilayah } \\
\hline Peringkat & Nilai daya saing & & \\
\hline 1 & 3,2008 & DKI Jakarta & Jawa \\
\hline 2 & 2,0817 & Jawa Timur & Jawa \\
\hline 3 & 1,4636 & Jawa Tengah & Jawa \\
\hline 4 & 1,3309 & Jawa Barat & Jawa \\
\hline 5 & 0,9956 & $\begin{array}{l}\text { Kalimantan Timur } \\
\text { dan Utara }\end{array}$ & Kalimantan \\
\hline 6 & 0,9658 & Sulawesi Selatan & Sulawesi \\
\hline 7 & 0,6697 & Bali & Bali \\
\hline 8 & 0,6482 & Kalimantan Selatan & Kalimantan \\
\hline 9 & 0,5486 & Sulawesi Utara & Sulawesi \\
\hline 10 & 0,3967 & DI Yogyakarta & Jawa \\
\hline 11 & 0,2579 & Banten & Jawa \\
\hline 12 & 0,0935 & Kepulauan Riau & Sumatra \\
\hline 13 & $-0,0019$ & Kalimantan Tengah & Kalimantan \\
\hline 14 & $-0,0767$ & Sulawesi Tengah & Sulawesi \\
\hline 15 & $-0,1837$ & Riau & Sumatra \\
\hline 16 & $-0,1951$ & Sulawesi Tenggara & Sulawesi \\
\hline 17 & $-0,2804$ & Kalimantan Barat & Kalimantan \\
\hline 18 & $-0,3062$ & Lampung & Sumatra \\
\hline 19 & $-0,3356$ & Nusa Tenggara Barat & Nusa Tenggara \\
\hline 20 & $-0,4338$ & $\begin{array}{l}\text { Kepulauan Bangka } \\
\text { Belitung }\end{array}$ & Sumatra \\
\hline 21 & $-0,4473$ & Gorontalo & Sulawesi \\
\hline 22 & $-0,4493$ & Sumatra Selatan & Sumatra \\
\hline 23 & $-0,4878$ & Sumatra Barat & Sumatra \\
\hline 24 & $-0,558$ & Sumatra Utara & Sumatra \\
\hline 25 & $-0,6513$ & Bengkulu & Sumatra \\
\hline 26 & $-0,6909$ & Aceh & Sumatra \\
\hline 27 & $-0,7292$ & Papua Barat & Papua \\
\hline 28 & $-0,7668$ & Jambi & Sumatra \\
\hline 29 & $-0,8476$ & Maluku & Maluku \\
\hline 30 & $-0,9933$ & Sulawesi Barat & Sulawesi \\
\hline 31 & $-1,306$ & Maluku Utara & Maluku \\
\hline 32 & $-1,3927$ & Nusa Tenggara Timur & Nusa Tenggara \\
\hline 33 & $-1,5192$ & Papua & Papua \\
\hline
\end{tabular}

Sumber: Giap and Amri, 2018(diolah)

Kebijakan yang dikeluarkan dapat terkendala penerapannya saat masuk ke tatanan pemerintah daerah. Desentralisasi yang terjadi di Indonesia saat ini telah menyebabkan 
perubahan dalam struktur tata kelola pemerintahaan. Desentralisasi yang terjadi secara politik di Indonesia tidak serta merta meningkatkan daya tanggap terhadap cakupan infrastruktur untuk publik lokal akan tetapi telah mengarah pada pengurangan rata-rata dalam investasi publik di daerah dengan kepala yang dipilih secara langsung (Kis-Katos and Sjahrir, 2017). Korupsi yang dilakukan pejabat publik, masih merupakan ancaman besar untuk membangun layanan publik dan birokrasi negara yang dapat dipercaya dan efisien. Meskipun desentralisasi dalam struktur tata kelola formal memiliki pengaruh yang menguntungkan pada akuntabilitas dan kontrol, namun pengaruh ini dapat tercemar akibat adanya calo atau penarikan biaya tidak resmi yang berbeda jumlahnya saat melakukan pembayaran (Holzhacker et al., 2015).

\section{Dukungan riset dan pengembangan}

Indonesia bukanlah negara yang mendukung sepenuhnya pengembangan riset dibandingkan negara lain di dunia maupun di wilayah ASEAN dengan negara yang memiliki tingkat perekonomian yang sama dengan Indonesia. Untuk ASEAN, pengeluaran untuk riset dan pengembangan di Indonesia masih jauh dibawah Singapura, Malaysia, Thailand dan Vietnam (Gambar 9) meskipun PDB Indonesia unggul dibandingkan negara-negara tersebut (Gambar 10). Berdasarkan data UNESCO tahun 2017 untuk negara Indonesia, penelitian terbanyak memakan biaya di Indonesia dilakukan oleh institusi pemerintah (839.164,9 ribu USD) diikuti Universitas (744.041,5 ribu USD) dan dunia usaha (547.051,0 ribu USD). Berbeda dengan negara ASEAN seperti Malaysia dan Thailand dengan penelitian terbanyak pada dunia usaha dan Universitas.

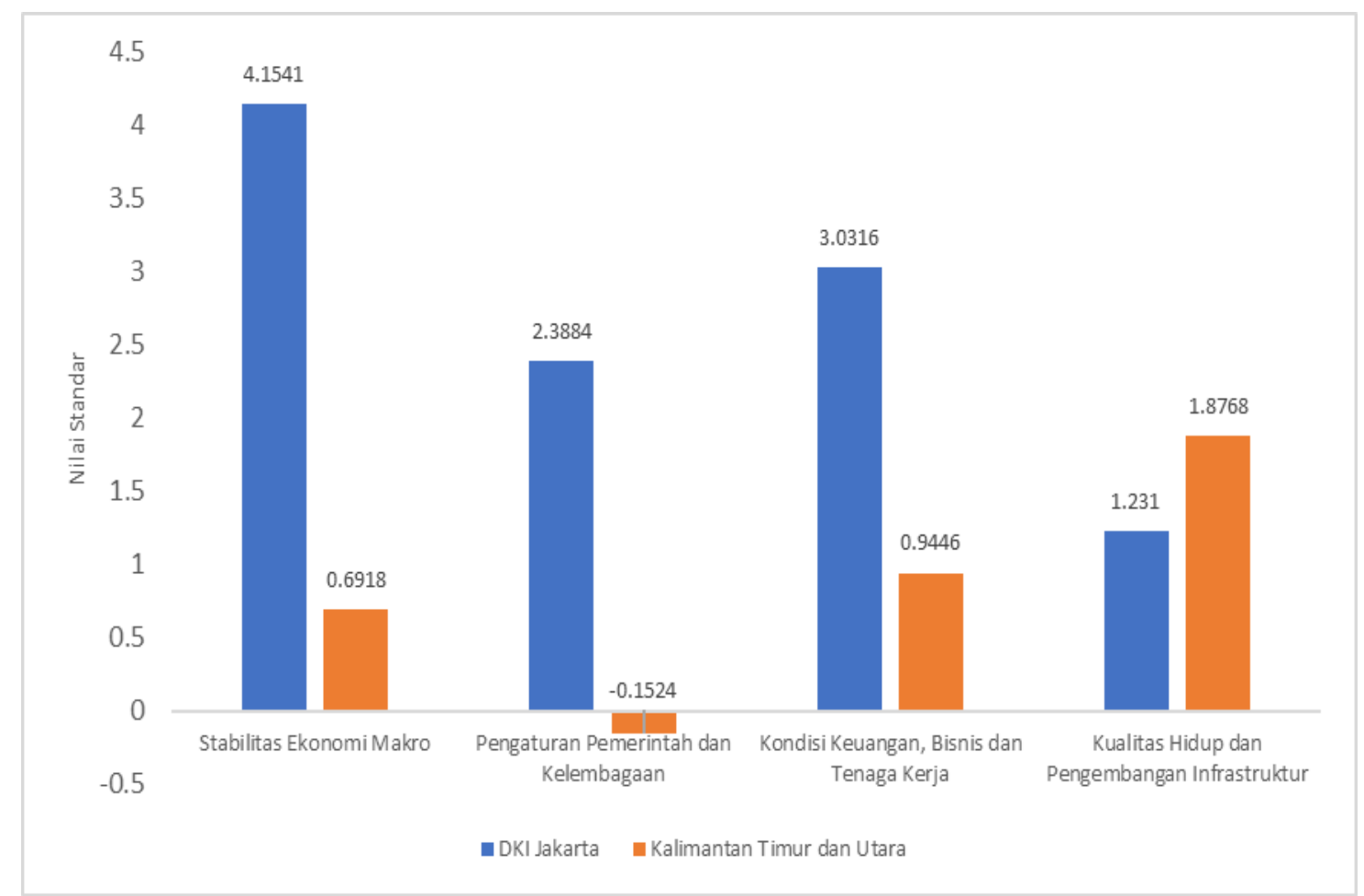

Gambar 7. Perbandingan DKI Jakarta dan Kalimantan Timur dan Utara dalam Faktor Pendukung Daya Saing

Sumber: Giap and Amri, 2018(diolah) 


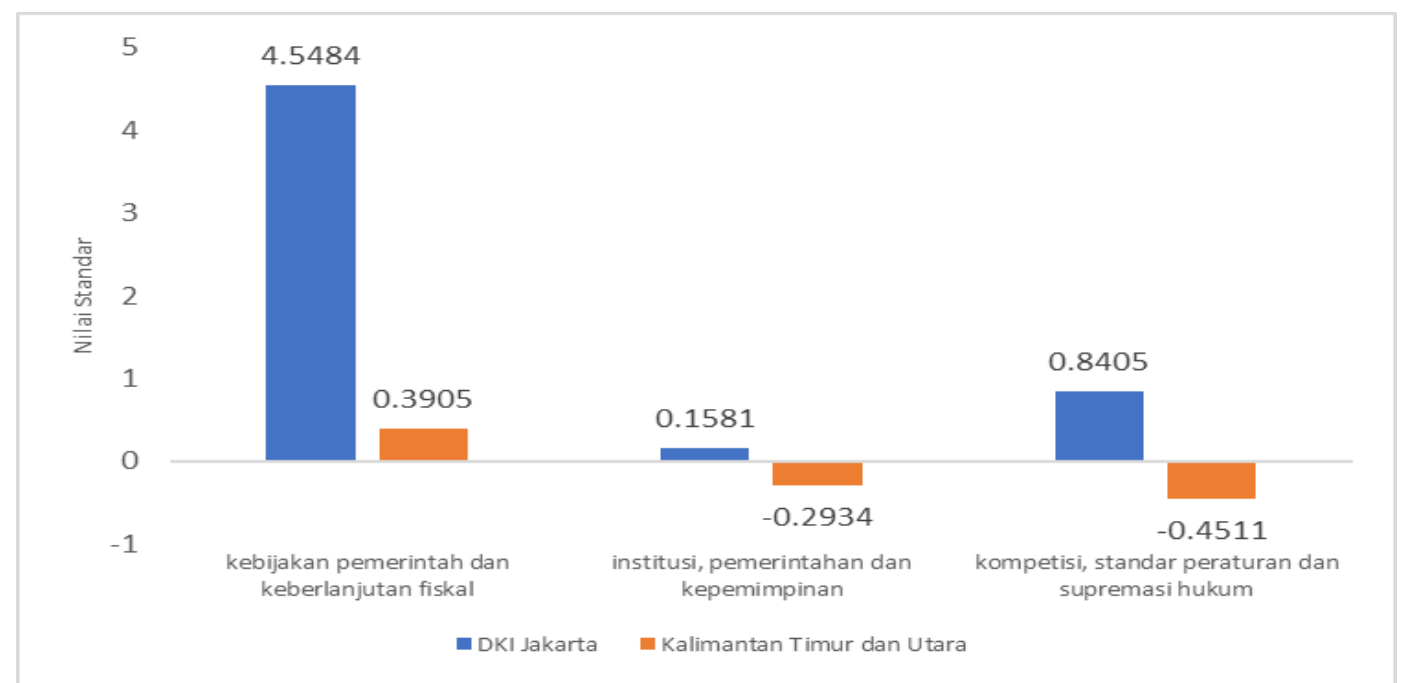

Gambar 8. Perbandingan DKI Jakarta dan Kalimantan Timur dan Utara dalam Sub Faktor Pengaturan Pemerintah dan Kelembagaan

Sumber: Giap and Amri, 2018(diolah)

$\square$ LABEL

Gambar 9. Pengeluaran untuk Riset dan Pengembangan (\% dari Produk Domestik Bruto, PDB) di beberapa negara anggota ASEAN kurun waktu 2007-2017 Sumber: Worldbank, 2019(diolah)

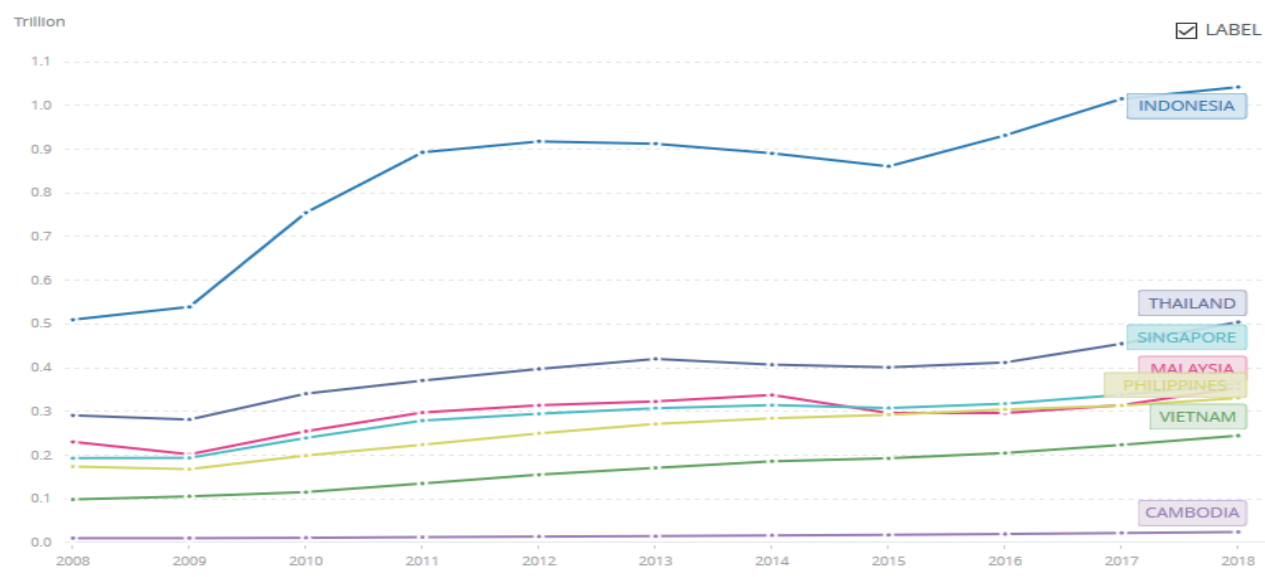

Gambar 10. PDB (dalam USD) untuk beberapa negara anggota ASEAN kurun waktu Periode 2008-2018

Sumber: Worldbank, 2019 (diolah) 


\section{KESIMPULAN DAN SARAN}

\section{Kesimpulan}

Pengembangan industri kendaraan listrik di Indonesia sulit untuk dilakukan dalam waktu jangka pendek maupun panjang dikarenakan: 1).Tingginya biaya dalam pengembangan kendaraan listrik terutama dalam memproduksi baterai kendaraan listrik. Meskipun Indonesia boleh berbangga diri memiliki bahan baku untuk pembuatannya, akan tetapi untuk memproduksi serta biaya perawatan dari baterai listrik dapat menjadi kendala untuk menarik orang berpindah ke kendaraan listrik. 2).Indonesia belum memiliki standar atau minimal memilih standar negara mana yang cocok dalam memproduksi kendaraan listrik. Standar dari tiap-tiap negara yang terlebih dahulu memproduksi kendaraan listrik berbeda-beda bergantung dari kondisi tiap-tiap negara. 3).Indonesia belum memiliki infrastruktur pembangkit listrik yang dapat mendukung jika diberlakukan secara nasional dikarenakan akan terjadi lonjakan permintaan listrik secara nasional.

Selain itu, perlunya dibangun tempat pengisian dibanyak tempat akan menjadi kendala selanjutnya dimana diperlukan infrastruktur yang menjamin keamanan saat pengisian baterai di tempat umum maupun di rumah. 4).Indonesia kurang menarik bagi investasi jika investasi diarahkan kedaerah diluar pulau Jawa. Hal ini karena masih kurangnya kerjasama antara pusat dan daerah yang mengakibatkan daerah di luar Jawa kurang menarik bagi investasi untuk masuk. 5).Belum adanya kebijakan atau paket insentif yang dapat menarik investasi perusahaan masuk maupun bagi individu terkait kendaraan listrik. 6).Masih lemahnya budaya riset dan pengembangan di Indonesia dibandingkan dengan negara lain terutama di ASEAN. Hal ini dapat menyebabkan investasi asing yang akan masuk ke Indonesia beralih ke negara tetangga yang lebih siap menampung keinginan investor.

\section{Saran}

Perlu adanya turunan yang jelas dari Peraturan Presiden Nomor 55 Tahun 2019 yang terbit pada 12 Agustus tentang percepatan program Kendaraan Berbasis Listrik yang dianggap dapat menjadi pembuka era kendaraan listrik di Indonesia. Aturan turunan ini diharapkan dapat menjadi paying hukum bagi investor yang ingin masuk ke Indonesia agar mendapat kepastian hukum dalam mengembangkan investasinya.

Peraturan turunan nantinya diharapkan dapat menjelaskan lebih detail terkait teknologi hybrid dan insentif produksi dan dikeluarkan oleh kementerian dan Lembaga terkait dan bekerjasama dengan dunia usaha dan juga akademisi.

\section{DAFTAR PUSTAKA}

Abas, N., Kalair, A., \& Khan, N. (2015). Review of Fossil Fuels and Future Energy Technologies. Futures, 69(May 2015), 31-49. DOI: 10.1016/j.futures.2015.03.003

Ahmad, A., Khan, Z.A., Saad A.M., \& Khateeb, S. (2018). A Review of the Electric Vehicle Charging Techniques, Standards, Progression and Evolution of EV Technologies in Germany. Taylor \& Francis Journal of Smart Science, 6,(1), 3653. https://doi.org/10.1080/23080477.2017.1420132

Ajanovic, A. (2015). The Future of Electric Vehicles: Prospects and Impediments. Wiley Interdisciplin Reviews (WIREs) Energy \& Environment, 4(6),521-536. https://doi.org/10.1002/wene.160 
Altenburg, T. (2014). From Combustion Engines to Electric Vehicles-A Study of Technological Path Creation and Disruption in Germany. Development Institute, Deutsches Institut für Entwicklungspolitik (DIE): German.

Badan Pusat Statistik. (2018). Statistik Listrik 2012-2017. Diakses dalam https://www.bps.go.id, Tanggal 12 Desember 2019, Pulul 12.30 WIB

Badan Pusat Statistik. (2019). Data Jumlah Kendaraan Bermotor di Indonesia. Diakses dalam https://www.bps.go.id, Tanggal 12 Mei 2019, Pulul 12.30 WIB

Bohnsack, R., Pinkse, J., \& Kolk, A. (2014). Business Models for Sustainable Technologies: Exploring Business Model Evolution in The Case of Electric Vehicles. Research Policy, 43(2), 284-300. DOI: 10.1016/j.respol.2013.10.014

Brady, J., \& O’Mahony, M. (2016). Development of A Driving Cycle to Eval Uate The Energy Economy of Electric Vehicles In Urban Areas. Applied Energy 177, 1 September 2016, 165-178. DOI: 10.1016/j.apenergy.2016.05.094

Bruijl, G.H.T. (2018). The Relevance of Porter's Five Forces in Today's Innovative and Changing Business Environment. Social Science Research Network (SSRN) Electron. 7 Juni Tahun 2018). 1-21, https://doi.org/10.2139/ssrn.3192207

CNBC News. (2019). Thailand is a 'leading beneficiary' of The Trade War, says Standard Chartered. Diakses dalam https://www.cnbc.com, Tanggal 12 November 2019, Pukul 12.00 WIB

CNN Indonesia. (2019). Analisis: Bank Indonesia Nilai Indonesia Tak Bisa Ekspor Mobil Listrik. Diakses dalam https://www.cnnindonesia.com, Tanggal 12 November 2019, Pukul 13.00 WIB

Dorri, A., Steger, M., Kanhere, S.S., \& Jurdak, R. (2019). A Blockchain-based Solution to Automotive Security and Privacy, Chapter 5, Blockchain Distributed. Systems Security.Wiley Online Library: Auatralia

Fauzia, M. (2019). Cita-cita Jokowi: Jadikan Indonesia Pusat Industri Mobil Listrik Dunia. Kompas. Diakses dalam https://money.kompas.com, Tanggal 12 April 2019, Pukul 12.30 WIB.

Gabungan Industri Kendaraan Bermotor Indonesia. (2019). Asean Auto Market (20072016).Diakses dalam https://www.gaikindo.or.id, Tanggal 25 Mei 2019, Pukul 12.30 WIB.

Giap, T.K., \& Amri, M. (2018). Slow Growth and Sluggish Manufacturing in Indonesia's Less Competitive Provinces: A Geweke Causality Analysis. Applied Finance and Accounting. 4(2), 2-14

Habib, S., Kamran, M., \& Rashid, U. (2015). Impact Analysis of Vehicle-to-Grid Technology and Charging Strategies of Electric Vehicles on Distribution Networks-A Review. Journal Power Sources 277, 205-214. https://doi.org/ 10.1016/j.jpowsour.2014.12.020

Han, W., \& Xiao, Y. (2016). Privacy preservation for V2G Networks in Smart Grid: A Survey. Computer Communications, 000(2016), 1-12

Hauser, A., \& Kuhn, R. (2015). Cell Balancing, Battery State Estimation, and Safety Aspects of Battery Management Systems For Electric Vehicles, Woodhead Publishing Series in Energy: Singapore

Heidrich, O., Hill, G.A., Neaimeh, M., Huebner, Y., Blythe, P.T., \& Dawson, R.J. (2017). How do cities support electric vehicles and what difference does it make?, Technological Forecasting and Social Change, 123(Oktober 2017),17-23.

Holzhacker, R.L., Wittek, R., \& Woltjer, J. (2016). Decentralization and governance in Indonesia. Decentralization Governance in Indonesia. Springer International Publishing: Switzerland 
Hu, J., Morais, H., Sousa, T., \& Lind, M. (2016). Electric Vehicle Fleet Management In Smart Grids: A Review of Services, Optimization and Control Aspects. Renewable Sustainable Energy Reviews. 56(28 April 2016), 1207-1226.

Kabalci, Y. (2016). A Survey on Smart Metering And Smart Grid Communication. Renewable Sustainable Energy Reviews.57(28 Mei 2016), 302-318.

Kang, N., Ren, Y., Feinberg, F.M., \& Papalambros, P.Y. (2016). Public Investment and Electric Vehicle Design: A Model-Based Market Analysis Framework With Application to a USA-China Comparison Study, Design Science, 2(e6), 1-42. https://doi.org/10.1017/dsj.2016.7

Kis-Katos, K., \& Sjahrir, B.S. (2017). The Impact of Fiscal and Political Decentralization on Local Public Investment in Indonesia. Journal of Comparative. Economics. 45, 344-365. https://doi.org/10.1016/j.jce.2017.03.003

Knezovic, K., Martinenas, S., Andersen, P.B., Zecchino, A., \& Marinelli, M. (2017). Enhancing the Role of Electric Vehicles in the Power Grid: Field Validation of Multiple Ancillary Services. IEEE Transactions on Transportation Electrification, 3(1), 201-209. doi:10.1109/tte.2016.2616864

Langbroek, J.H.M., Franklin, J.P., \& Susilo, Y.O. (2016). The Effect of Policy Incentives on Electric Vehicle Adoption. Energy Policy, 94(2016), 94-103. https://doi.org/10.1016/j.enpol.2016.03.050

Lévay, P.Z., Drossinos, Y., \& Thiel, C. (2017). The Effect of Fiscal Incentives on Market Penetration of Electric Vehicles: A Pairwise Comparison of Total Cost of Ownership. Energy Policy 105(2017), 524-533. https://doi.org/10.1016/j.enpol. 2017.02.054

Li, W., Long, R., Chen, H., \& Geng, J. (2017). A Review of Factors Influencing Consumer Intentions to Adopt Battery Electric Vehicles. Renewable Sustainable Energy Reviews. 78(Oktober 2017), 318-328. https://doi.org/10.1016/j.rser. 2017.04.076

Masiero, G., Ogasavara, M.H., Jussani, A.C., \& Risso, M.L. (2016). Electric Vehicles in China: BYD Strategies and Government Subsidies. RAI Revista de. Administração e Inovação, 13(1), 3-11, https://doi.org/10.1016/j.rai.2016.01.001

Mehar, S., Rémy, G., Zeadally, S., \& Senouci, S.M. (2015). Smart Management System for a Fleet of Electric Vehicles. IEEE Transaction Intelligent Transportation Systems 16(3), 1401-1414.

Onyusheva, I., Naing, C.T., \& Zaw, A.L. (2019). The Us-China Trade War: CauseEffect Analysis. The EUrASEANs: Journal on Global Socio-Economic Dynamics, 1(14), 07-15. https://doi.org/10.35678/2539-5645.1(14).2019.07-15

Palmer, K., Tate, J.E., Wadud, Z., \& Nellthorp, J. (2018). Total cost of ownership and market share for hybrid and electric vehicles in the UK, US and Japan. Appl. Energy 209, 108-119. https://doi.org/10.1016/j.apenergy.2017.10.089

Ruiz, V., Pfrang, A., Kriston, A., Omar, N., Van den Bossche, P., \& Boon-Brett, L. (2018). A Review of International Abuse Testing Standards and Regulations For Lithium Ion Batteries in Electric and Hybrid Electric Vehicles. Renewable and Sustainable Energy Reviews, 81(1), 1427-1452. https://doi.org/10.1016/j.rser. 2017.05.195

Shareef, H., Islam, M.M., \& Mohamed, A. (2016). A Review of The Stage-of-The-Art Charging Technologies, Placement Methodologies, and Impacts of Electric Vehicles. Renewable and Sustainable Energy Reviews, 64(Oktober 2016),403-420. https://doi.org/10.1016/j.rser.2016.06.033

Shaukat, N., Khan, B., Ali, S.M., Mehmood, C.A., Khan, J., Farid, U., Majid, M., 
Anwar, S.M., Jawad, M., \& Ullah, Z. (2018). A Survey on Electric Vehicle Transportation Within Smart Grid System. Renewable and Sustainable Energy Reviews, 81(1), 1329-1349. https://doi.org/10.1016/j.rser.2017.05.092

Tan, K.M., Ramachandaramurthy, V.K., \& Yong, J.Y. (2016). Integration of Electric Vehicles in Smart Grid: A Review on Vehicle to Grid Technologies and Optimization Techniques. Renewable and Sustainable Energy Reviews, 53(Januari 2016), 720-732. https://doi.org/10.1016/j.rser.2015.09.012

Till Bunsen, Cazzola, P., D’Amore, L., Gorner, M., Scheffer, S., Schuitmaker, R., Signollet, H., Tattini, J., \& Paoli, J.T.L. (2019). Global EV Outlook 2019 to Electric Mobility. Diakses dalam https://www.iea.org/reports/global-ev-outlook2019, Tanggal 12 Desember 2019, Pukkul 9.00 WIB

UNESCO. (2017). R\&D Spending by Country. Diakses dalam http://uis.unesco.org, Tanggal 19 Desember 2019, Pukul 12.30 WIB

Valta, J., Makinen, S., Kotilainen, K., Rautiainen, A., \& Jarventausta, P .(2018). Comparison of Innovation Policies or Electric Vehicle Business Ecosystems. Institute of Electrical and Electronics Engineers (IEEE): Lodz, Poland. https://doi.org/10.1109/EEM.2018.8469785

Woo, J.R., Choi, H., \& Ahn, J. (2017). Well-to-Wheel Analysis of Greenhouse Gas Emissions for Electric Vehicles Based on Electricity Generation Mix: A Global Perspective. Transportation Research Part D: Transport and Environment, 51(Maret), 340-350. https://doi.org/10.1016/j.trd.2017.01.005

Worldbank. (2019). Foreign Direct Investment, Net (BOP, Current US\$) - Thailand, Indonesia, Vietnam, Malaysia. Diakses dalam https://data.worldbank.org, Tanggal 12 Desember 2019.

Worldbank Group. (2019). Comparing business regulation in 190 Economies. Diakses dalam https://www.doingbusiness.org, Tanggal 12 November 2019.

Worldbank. (2019). Research and Development Expenditure (\% of GDP) - Indonesia, Thailand, Vietnam, Malaysia, Cambodia, Philippines, Singapore. Diakses dalam https://data.worldbank.org, Tanggal 20 Desember 2019. 